ukrainian translation and original of E. M. Remarque's novel «Flotsam» proves the effectiveness of this research method in relation to the works of the German writer and raises the issue of further study and analysis of both general cultural and individual authorial concepts of E. M. Remarque.

\title{
References:
}

1. Maslova, V. A. (2007). Vvedenie v kognitivnuyu lingvistiku: Uchebnoe posobie. Moscow: Nauka.

2. Remark, E. M. (2020). Chas zhyty i chas pomyraty. Liuby blyzhnoho tvoho (Flotsam). Kharkiv: «Knyzhkovyi Klub «Klub Simeinoho Dozvillia». (in Ukrainian)

3. Slovnyk ukrainskoi movy Akademichnyi tlumachnyi slovnyk (1970-1980). Retrieved from: http://sum.in.ua

4. Online Duden. Retrieved from: https://www.duden.de

5. Remarque, E. M. (1998). Liebe deinen Nächsten (Flotsam). Keln (Kiepenheuer\&Witsch)

\section{ANNE BRONTË'S LITERARY LEGACY: THE UKRAINIAN DIMENSION}

\section{Kristina Gusenko ${ }^{1}$}

Research Advisor: Olha Honcharova ${ }^{2}$

DOI: https://doi.org/10.30525/978-9934-26-002-5-13

In 2020, the world literary society, especially the Brontës' appreciators, celebrated the $200^{\text {th }}$ birth anniversary of the youngest of the three sisters Anne (1820-1849) - that completed the Brontë family bicentenaries marathon of the last five years. The festivities alongside with the academic discussions revealed the urgent problem of the total underestimation of Anne Brontë's literary heritage. The title of Marianne Thormählen's paper «Standing Alone: Anne Brontë out of the shadow» (2014) explicitly characterizes the place the Yorkshire authoress occupied in the history of English literature at the beginning of the twenty-first century [9]. However, it also marks the rapid growth of interest to the shadowed writer. During the following years and till nowadays, a number of brilliant biographies and monographs which bring Anne «out of the shadow» have appeared: Juliet Barker's The Brontës (Abacus 2014), Catherine Rayner's The Brontë Sisters: Life, Loss \&

\footnotetext{
${ }^{1}$ H.S. Skovoroda Kharkiv National Pedagogical University, Ukraine

${ }^{2}$ H.S. Skovoroda Kharkiv National Pedagogical University, Ukraine
} 
Literature (Pen \& Sword History 2018), Samantha Ellis's Take Courage: Anne Brontë and the Art of Life (Vintage Publishing 2018), Adelle Hay's Anne Brontë Reimagined: A view from the twenty-first century (Saraband 2020), Nick Holland's In Search of Anne Brontë (The History Press 2016) and Crave the Rose: Anne Brontë at 200 (Valley Press 2020) by the same author.

In Ukraine, similarly to other national literatures of the Eastern Europe, the figure and writings of Anne Brontë still remain obscure. Needless to say, that the bulk of critical works are dedicated to Charlotte and Emily Brontë whereas Anne's two novels Agnes Grey (1847) and The Tenant of Wildfell Hall (1848), let alone her poems, stay in the background. As a result, her works have never been the separate subject of literary studies in Ukraine. There are only several prefaces, critical articles and essays dedicated to «the third Bronte sister's» literary heritage which tend to have fragmentary features [2; 6; 7; 8]. Agreeing with Marianne Thormählen's assertion that «Anne Brontë's novels are as worthy of reading and study as her sisters'» [9, p.331], we aim to summarize the level of knowledge on Anne Brontë in the Ukrainian literature study and outline the further perspectives of the research.

In the second half of the twentieth century, Ukrainian literary critics Mykhailo Rudnytsky and Tetyana Denysova played an important role in popularizing novels of the Brontë sisters in Ukraine. They were mostly concentrated on Wuthering Heights (1847) by Emily and Jane Eyre (1847) by Charlotte Brontë. A lot of scientific research is devoted to both novels. They include the articles by such talented Ukrainian critics as Yevhen Besarab, Olha Bundrovska, Bohdan Telenko and others.

As for Anne's works, they were translated into Russian and got recognition in Russian literary criticism earlier than in Ukraine [1; 5]. Noteworthy, that both Anne's novels were translated into Russian in 1990 and by now there are several translations whereas Agnes Grey still has not been translated into Ukrainian. What is more, the novel The Tenant of Wildfell Hall was translated into Ukrainian only once, by Natalia Titko in 2009, but the edition has been criticized for certain flaws.

According to Nadiia Nazarenko, Titko's translation of the novel is not entirely appropriate. She notes that the surnames of the main characters have been changed, for instance, 'Hantington' instead of 'Hantingdon', 'Gelena' instead of 'Helen' etc. Also, in her translation, Titko omitted the names of some chapters, despite the fact that they have semantic and ideological importance. Besides, the descriptions of the characters' emotions and facial expressions are also omitted. Nazarenko concludes that inaccuracies and omissions of the Titko's translation distort to some degree Anne Brontë's artistic and expressive picture of the world [7]. Nonetheless, Natalia Titko managed to convey the figurative structure of the novel and, following the original text, accurately 
translated the descriptions of nature, the important details of the personages' lives, and transferred the uniqueness of their language [8].

The Russian critic A. Druzhynina claims that Anne's great achievement is that she was the first English female writer who demonstrated «the women's revolt and desire to leave the family, her attempts to earn own living» [1, p. 198]. It is interesting that the idea of women's emancipation, successfully produced in the English literature by Anne Brontë, has been deeply rooted in the Ukrainian literature. Indeed, such Ukrainian female writers as Marko Vovchok (also known as Maria Vilinska), Lesia Ukrainka, Khrystyna Alchevska and Olha Kobylanska absolutely shared Anne's literary views.

As stated by Ukrainian critic N. Nazarenko, who completed a $\mathrm{PhD}$ dissertation «Reception of the Brontë sisters' literary works in Ukrainian literature» (2011), the literary modes and styles of Anne Brontë and the most prominent Ukrainian female writers of the nineteenth - early twentieth centuries (Olha Kobylanska, Lesia Ukrainka, Natalia Kobrynska and others) are considerably similar. For instance, all of them demonstrate the hardships of women's lives, except that in Anne's novels there are less secrets and fatal or tragic episodes. Also, her novels usually introduce the realistic image of the world while the novels of Natalia Kobrynska and Lesia Ukrainka have the features of Romanticism (mostly Neo-Romanticism) and the elements of gothic style. And even the British writer and literary critic Muriel Spark, quoted by Nazarenko, emphasized that Anne was the least romantic and the most realistic of the Bronte sisters: «Charlotte totally fails to consider, either the representative status of Huntingdon or Anne's achievement in creating him. Yet the fact remains that for every rough idea, like Rochester, and for every single Heathcliff, there exist a score of Huntingdons» [8, p. 104].

Nazarenko especially emphasizes that the styles of Anne Brontë and Natalia Kobrynska are largely similar. They both bring to light the problems of marriage and women's independence, conflict of generations etc. But it is important to say that Ukrainian female writers combined the topic of women's individual growth with the problem of revival of the national consciousness of Ukrainian woman and her role in the society.

Another Ukrainian critic Mykhailo Krupka claims that for Brontë sisters, particularly for Anne, there was no problem of liberating the nation because the British Empire, the sisters' motherland, was the world's wealthiest and most powerful nation in the nineteenth century. That is why the problem of social, cultural and property inequality between women and men was more important for the English writers at that period of time than for writers of other cultures [3; 4].

All in all, there is still a huge gap in Ukrainian reception of Anne Brontë's literary legacy. And though English scholars have done a significant progress 
in accumulating knowledge on the shadowed youngest authoress from the Yorkshire family, Thormählen's statement that «Anne Brontë is a field of inquiry in which much remains to be done» is still relevant for other national literatures, including Ukrainian [9, p. 337]. The increase of attention to feminism and women's personal development, particularly in Ukraine, as well as the growth of interest to comparative studies and connections between national literatures, will definitely bring the Ukrainian researchers of Anne Brontë's literary heritage to a new level.

\section{References:}

1. Druzhynina A.A. (2000) Sestry Bronte [The Bronte Sisters]. Istoriya zarubezhnoy literatury 19 veka $v$ yego sovremennom zvuchanii [The history of foreign literature of the 19th century in its modern acceptance]. Moscow: Nauka, pp. 197-226.

2. Honcharova O.A. (2019) «My tri sestry» B. Morrisona kak intertekst: istoriya sem'i Bronte skvoz’ prizmu chekhovskoy p’yesy [«We are Three Sisters» by B. Morrison as intertext: The Bronte family through the prism of Chekhov's play]. Vcheni zapysky TNU imeni V.I. Vernadsjkogho. Serija: Filologhija. Socialjni komunikaciji, vol. 30 (69), no. 2, issue 2, pp. 89-94. DOI: https://doi.org/10.32838/2663-6069/2019.2-2/18

3. Krupka M.A. (2004) Emansypacijni tendenciji v ukrajinsjkij zhinochij prozi kincja XIX - pochatku XX stolitj [Emancipation tendencies in Ukrainian women`s prose of the late 19th - early 20th centuries] (PhD Thesis), Kyiv.

4. Krupka M.A. (2004) Zhinocha proza doby modernu: koncepcija novogho gheroja [Women`s prose of the modern era: the concept of a new hero]. Visnyk Ljvivsjkogho universytetu. Serija: Filologhija, vol. 33(1), pp. 41-48.

5. Mikhalskaya N. (1990) Tretya sestra Bronte [Third Sister Bronte]. Bronte A. Agnes Grey. Neznakomka iz Uayldfell-Kholla. Stikhotvoreniya [Bronte A. Agnes Grey. The Tenant of Wildfell Hall. Poems]. Moscow: Khudozhestvennaya literatura, pp. 5-16.

6. Nazarenko N. (2007) Poetyka romanu Anne Bronte «Neznajomka z Uajldfelkholu» [The Poetics of Anne Bronte`s Novel «The Tenant of Wildfell Hall»]. Literatura. Folklor. Problemy poetyky: Zb. nauk.pracj, vol. 28, issue 1. Kyiv: Tvim inter, pp. 558-565.

7. Nazarenko N. (2010) Svojeridnistj ukrajinsjkoji recepciji tvorchosti sester Bronte [The features of the Ukrainian reception of the Bronte sisters' creativity]. Aktualjni problemy filologhiji: movoznavstvo, literaturoznavstvo, metodyka vykladannja filologhichnykh dyscyplin: Zb. nauk. statej, vol. 2, pp. 169-174.

8. Nazarenko N. (2011) Retseptsiya tvorchosti sester Bronte v ukrayins'kiy literaturi [Reception of the Brontë sisters' literary works in Ukrainian literature] (PhD Thesis). Kyiv: T.H. Shevchenko Kyiv National University.

9. Thormählen M. (2014) Standing Alone: Anne Brontë out of the shadow. Brontë Studies, vol. 39, no. 4, pp. 330-340. DOI: https://doi.org/10.1179/1474893214Z. 000000000128 